\title{
Feminist Research in Misogynistic Times
}

\author{
An Interview with Drude Dahlerup
}

by Lea Skewes

Post-Doctoral Researcher, Political Science at Aarhus University

\section{Introduction}

I met with Drude Dahlerup who is a Professor of Political Science at Stockholm University and an Honorary Professor at the Institute for Social Sciences and Business and the Centre for Gender, Power and Diversity at Roskilde University. She was one of the pioneers in the Danish Redstocking Movement, that kickstarted the second wave of feminism. Furthermore, she was part of establishing Women's Studies, which she describes as a flourishing, international, scientific discipline. Throughout her career, she has worked on the topics of women's political representation, gender quota systems and social movements including the history of Women's Movements. With the goal of empowering women and increasing women's political representation in countries all over the world, she has put her academic knowledge into practice in the role as international advisor for the United Nations, the Inter-Parliamentary UNION (IPU), the Danish Institute for Parties and Democracy to Bhutan, Egypt, Sierra Leone a. o. She has been a vocal, feminist researcher who has never been afraid to push controversial feminist agendas.
In this interview, she offers her personal experience with resistance to women in academia and feminist science in general, as well as her unique insight into Danish politicians' current approach to gender equality and the \#MeToo Movement. She points out that, currently, Denmark is falling behind on gender equity measures, because we remain stuck in a focus on women's alleged shortcomings, rather than focusing on the patriarchal structures that hinder equal access to high status positions such as academia or political seats in parliament.

\section{Situating Drude Dahlerup}

Skewes: "I would like to start by asking you to situate yourself both as a feminist and as a researcher - what kind of labels would you take on?"

Dahlerup: "I would say that I'm part of the first generation of people who created Women's Studies, which later became Gender Studies. In the beginning, we were only one or two feminist researchers at each Institute, and we would not have survived if we had not been situated in the larger Women's 
Movement, locally, nationally and globally. This movement was absolutely essential in order to handle the resistance we met within academia, because it convinced us that we were on the right track! The Redstockings Movement in Aarhus (the second biggest city of Denmark) was well known for being the most academic branch of the Redstockings Movement in Denmark. We presented our academic analyses of women's oppression in society throughout history in meetings and seminars in the movement. In fact, many of the university's first Women's Studies master theses started as movement papers! The other absolutely essential element which we as Danish feminists in political science or history needed to succeed in academia, was our Nordic colleagues. We started to compensate for the isolation at our institutes by making Nordic co-operations. We wrote the first Nordic comparative book on women and democracy called Unfinished Democracy: Women in Nordic Politics (1986), financed by the Nordic Councils of Ministers. That would also be my advice to younger scholars, if they feel isolated within their local academic community: go international! The newest academic trends within feminist studies are often presented at Nordic, European and international seminars and conferences - and it is here you may meet your future academic collaborators (see Dahlerup 2010c).

However, the new Women's Studies discipline was not considered a proper science in the beginning. But today, Gender Studies or Feminist Studies is an acknowledged international discipline. And I am so delighted to see that we now have Women's Research Centres, Gender Studies Centres, Gender and Diversity Centres and Gender Studies Networks everywhere in the world. We also see these types of centres and networks expanding rapidly in the Arab world, where I have worked a lot in recent years. Now, you can also find many international scientific Feminist Studies journals and you will find articles written from a gender perspective in almost all scientific journals today - even in natural and computer science journals. There is also an increasing number of $\mathrm{PhD}$ thesis that make use of feminist theory and perspectives. Women's Studies started out as a discipline in which you would know almost all that was written in the field, but now, feminist/gender perspectives have been developed within almost all scientific disciplines and subfields. Of course, not everybody likes that, and most recently, Victor Orbán's government banned 'gender studies centres' in Hungary as part of a new conservative backlash against the increase in women's and sexual minority rights. You find a similar backlash dynamic in Latin America under the strange heading of 'anti-gender' or 'anti-gender ideology'. This reflects that the change is controversial and that there is a backlash, but change has taken place."

\section{Resistance to a Feminist Perspective in Academia}

Skewes: Can you offer some examples of the resistance to the feminist perspective you experienced when you first started in academia?"

Dahlerup: "In 1963, when I started studying political science, a relatively new discipline at the time, there were not a single female teacher employed. On top of that, we were only about $10 \%$ women amongst the political science students and not all of us were active in the Women's Movement. This meant that if you put your hand up in order to ask a feminist question, then all your classmates would laugh at you because a feminist perspective was considered ridiculous. We did of course sometimes raise our hand to pose critical questions anyway, but most of the time we did not. I remember that sometimes, after daring to ask one of these questions, I would leave the class room trembling a little bit, and then I would think twice before I opened my mouth again."

Skewes: "So, even posing a feminist question was considered ridiculous?"

Dahlerup: "Yes absolutely! I also remember that the teachers were not pronouncing the word 'kvinde' (meaning 'woman' in Danish) properly in class, they would all pronounce it 'qvinde' which made a mockery of the category women itself. So, even 
the social category of women was disrespected. This meant that we were left to study and write from a feminist perspective all on our own."

Skewes: "But that is really worrisome - you were not even allowed a voice! You were allowed to write but you couldn't verbalize what you were writing about in class!"

Dahlerup: "I would rather emphasize, that even though we were not 'allowed' we did it anyway. I remember one of my first essays in economics in which I chose to write about equal pay. The teacher wrote in the margin of the essay, whether we couldn't just give the women a small increase in pay rather than actual equal pay? A comment, which revealed that equal pay was a completely new concept or consideration for him.

Another example of the kind of resistance I experienced was from one of my colleagues who asked me 'why are you not doing research with a broader scope?' - which of course implied that focusing on women or gender differences was too narrow a scope, while focusing exclusively on men and men's work was not. Similarly, when I wrote my master's thesis. It was one of the first theses in political science written from a feminist perspective, and the external examiner, the famous professor of economics Jørgen Dich, wrote that this was a very good essay (I received the highest possible mark). But he still felt the need to add 'But I don't agree.' Since this was a 400 pages thesis that analysed the different political ideas about women's emancipation among $19^{\text {th }}$ century French Utopian Socialists and German Marxists, this remark was puzzling to me. My interpretation was that he probably meant that he did not like the subject."

Skewes: "How did you manage this kind of resistance or critique of you and your field?"

Dahlerup: "I think you have to be stubborn and believe that you are on the right track in order to handle it. And you also need other people around you in order to survive. No doubt, my choice of research area contributed to the fact, that it took 15 years for me to get a tenured position, which was unusual at that time. Feminism was not considered a good fit for the university, so tenure track positions were hard to come by.

Another example of early resistance was when I was part of establishing the Women's Studies Centre, CEKVINA, at Aarhus University. I remember how I told my colleagues over the lunch table that we had decided to open up the Centre to include other faculties than the Social Sciences and Humanities. To this information one of my male colleagues responded 'I also love when women open up.' And still to this day, I regret that I just walked out in anger. Later, however, I learned that a good colleague of mine had challenged him after I left the room. So, even though I did not take that fight a colleague did. Experiences like this has taught me that some people cannot be persuaded that gender equality should be taken seriously, and you just have to move around them and find other allies in order to achieve progress.

In general, when studying gender inequality in academia, I must conclude that the universities are the last bastion in society which has not yet realized, or only slowly have started to realize, that there is a gender structure we need to change in order to reach equal opportunities for women in academia."

Skewes: "Okay, so you think that most of the Danish society has caught on but that universities are not quite there yet?"

Dahlerup: "I would say that the rest of society has understood the gender equality message, but that the universities are the last institutions to realize that there is a gender structure embedded in the walls of the academic institutions. The reason for this is that the gender structure critique hits a nerve in those particular institutions because the universities have a self-perception of being meritocracies. They have always assumed that the people who get positions are the most qualified, and they have been blind to the built-in biases against women and against minorities. But we find biases at many levels, for instance in (a) who is encouraged to apply for PhD scholarships, (b) in narrowly formulated calls for new professorships, 
and as newer research has shown (c) sometimes even in the distribution of external research funds. I do not think it is a coincidence that those of us who were in Gender Studies, did not do research on the universities themselves but rather studied gender structures outside the universities. But you, for instance, are now bringing feminist research on universities into academia, as I have done in Sweden. It is very important, but it is also burdensome to work on changing your own organization from the inside" (Dahlerup 2010a; Skewes, Skewes \& Ryan 2019).

Skewes: "Yes, it creates challenging dynamics."

Dahlerup: "Yes, I like the word challenging dynamics."

\section{Politics or Science - Struggles over Perceptions of Objectivity}

Skewes: "What you are describing lays out both how you were received in academia and how feminist approaches to gender equality are not always being heard or welcomed. But do you personally think that your activism fuelled or conflicted with your research?"

Dahlerup: "I think it can be both positive and negative to combine activism and research. It was absolutely necessary to be part of an activist movement in order to overcome the resistance. So, in this sense the activism fuelled the research. But the flipside of that coin was that we were criticised for being 'political'. It worked against us that our feminist work spurred a negative gut feeling in many men. For instance, if you tried to start a scientific discussion, many male colleagues would answer talking about emotional experiences in their private life rather than about research - clearly misunderstanding what was being debated. One of the effects of this bracketing off of feminist research as just political ideology, was that the universities during the 1970s and 1980s simply did not offer any positions in Women's Studies. If you got a job at this time, it would be in spite of doing gender research, not because of it. This reflected that our work was considered politics, rather than science. We had to prove that this was in fact a scientific discipline. In my very first article from 1974, which caused blood, sweat, and tears, I wrote that our critique of the assumed gender-blind science was not just a moral critique, but 'a critique, which attacks the scientific level of existing research and teaching, based on the opinion that a distorted and incomplete picture of reality has been given.' I pointed out that it was an example of low academic standards if you, for instance, considered 'family' and 'women' natural categories that were never changing."

Skewes: "So, you pointed out some of the scientific problems which arise from a male-centric perspective?"

Dahlerup: "Yes, but our response to the critique that gender studies was 'political' and 'ideological' was in accordance with all critical analyses of the time, that no science is value free. I don't adhere to any concept of objective science. What is important in science is that the values are made explicit. You should state the purpose and approach of your research openly. These standards are no different than if you work on the climate issue or health issue or any other subject matter. In a recent article entitled 'The Impact Imperative: Here Come the Women' by Sara Childs and Rosie Campbell, they talk about the feminist imperative which is the fact that we aim for change with our type of research. In this way, it is very similar to doing research on climate change or poverty in the world. If you do research on working conditions in an organization, then you want working conditions to improve, right? You want to observe and report on the current situations in order to change them for the better. So, in fact the hope of change is not unique to feminist science. Starting from this idea of the feminist imperative, Sarah Child and I move the discussion one step further in a recent article, by asking what effects feminist scholars, as change actors, actually have upon whom, when, and through what channels? In that article, we used our own experiences of 
research and counselling about empowerment of women in politics as a case" (Childs \& Dahlerup 2018).

Skewes: "So, the original critique was that it didn't qualify as science?"

Dahlerup: "Yes, it was not considered a science in the beginning. But we did manage to get funding from the Research Councils in Denmark. And, like in all Nordic countries, cross-party networks of Danish women politicians during the 1980 s made parliament provide money for centres, positions and projects, thus bypassing and even softening the resistance to gender research at the universities. Now it is an internationally expanding and acknowledged discipline, and there is so much going on in the field!

\section{The Taboo of Quotas}

Skewes: "You capture the many ways in which feminists and feminist science was marked as highly controversial within the universities. Are there any research topics that you have experienced particular resistance to?"

Dahlerup: "No, my research has not been as controversial as for instance research on topics like domestic or sexual abuse of women, as the Swedish-Norwegian scholar Eva Lundgren experienced. If the results of your research are unwanted, then you will be scrutinised extra on your research methods, as all feminist scholars have experienced. You just have to be good! In my own work, it is probably gender quotas, which have tapped into the greatest Danish taboo. When I translated my English book Has Democracy Failed Women? and made a Danish version, Demokrati uden kvinder? (Dahlerup 2018b), I expanded the chapter on gender quotas in order to invite Denmark into this global discussion, which, at the moment, we are not taking part in. This is an important discussion because, although controversial, quotas are one of the gender equality instruments which are being used more and more in political life all over the world. Quotas are even slowly starting to be applied in recruitment of board members of companies.

Back in 2006, I edited the first global book about this new trend, after having invited researchers from all major regions in the world to a conference in Stockholm. My present research on quotas shows that more than half of the world's countries currently is using some kind of gender quotas in order to rapidly change unwanted gender inequalities in political life. The legitimacy and effectiveness of gender quotas in politics depends on three things: (1) how the problem of women's under-representation is diagnosed; (2) to what extend the type of gender quotas that are adopted matches the electoral system in place; and (3) the general discourse on women's position in a society (Dahlerup 2006; Dahlerup \& Freidenvall 2010; Dahlerup \& Antíc Gaber 2017). Gender quotas is an instrument which, when constructed in the right way and with sanctions for noncompliance, is highly efficient. I often think that at least part of the resistance to quotas is actually that it is so efficient! If you implement quotas correctly you will see changes, and not everyone wants to break male dominance."

\section{Feminist Work in Misogynistic Times}

Skewes: "What do you think it means for feminists and feminist researchers in particular that we currently have a misogynistic and homophobic American President? Do you think that this misogyny and homophobia spills over into international discourse?"

Dahlerup: "Absolutely! I have been writing about this because I do think that, in the future, we will see an increased polarisation between feminists of all genders and anti-feminists. I think that many people thought that after neoliberalism we would have some kind of leftism again. However, already then, I predicted that after neoliberalism we would have conservatism. Kuhar and Paternotte's important book aims to uncover the actors who are driving this very ugly conservative 
mixture of sexism, homophobia, xenophobia and anti-immigrant movements. Donald Trump in America, Jair Bolsonaro in Brazil, Rodrigo Duterte in the Philippines, Viktor Orbán in Hungary and Andrzej Duda in Poland represent this new trend, which without any doubt should be labelled anti-feminist. In this book, the authors uncover many reasons for this, one of them being the unholy alliance between extremist right-wing populists, Christian evangelists, and the conservatives in the Vatican. But there are also many other forces at play, Steven Bannon being one of them. Of course, these extremists are not the major global force, but unfortunately they can win elections. These authors also uncover that in many places in Eastern Europe, and, I will add, in Latin America - some right-wing movements today use the concept of 'anti-gender' in English to expose an alleged foreign origin of feminism. However, the term is very unspecific, what does anti-gender mean? Sometimes they claim that they are against 'gender', whatever that might mean. But there is no doubt that they see the feminist, queer and transgender movements as a threat to the traditional family and to male dominance. Which in a way is correct! Resistance to \#MeToo and to the Black Lives Matter movement is part of the same trend.

Apart from these very resourceful right-wing movements, misogynists are very active on social media. This type of resistance is predominantly populated by marginalised men who are often called the 'losers of globalisation' in insecure job positions. Logically, they should be attacking the financial elite, but instead they attack women who are active in public life. Maybe because this is easier than attacking the powerful elite men. When I talk about a future increased polarization in my book Has Democracy Failed Women? (Dahlerup 2018a), it is because we also, at the same time, see that the women's movement has never been stronger, globally. This is illustrated by the Women's Marches and the \#MeToo Movement, which shows that women are not going to give up or give in!

Some people, even some feminist researchers, claim that women are constructing themselves as 'victims' when they protest in the \#MeToo movement. I disagree. The feminist movement is a political movement, and claiming your rights does not make you a victim! You wouldn't argue that a labour movement demonstration for the eight-hour workday in the 1920s made workers into victims, would you?"

Skewes: "Why do you think there is this strong anti-feminist or 'anti-gender' rise now?"

Dahlerup: "I think that this is partly a backlash caused by the fact that women are claiming more space. Women are in fact becoming more visible in the public spaces and debates. We do have more women in politics, even if politics is still male dominated. But because male dominance has been the norm for thousands of years, many of these people interpret $20-30 \%$ women in politics as female dominance."

Skewes: "But where does that misperception that women are taking over come from?"

Dahlerup: "The Institute for Human Rights made a study which showed that $26 \%$ of men and $14 \%$ of women actually believe that we currently have gender quotas at elections in Denmark (Institute for Human Rights 2019); and we have nothing of the sort. In our new book on the Danish political gender equality regime, which I edit together with Anette Borchorst and Jørgen Goul Andersen we show almost identical results in the book's population survey. When it comes to academia, people observe that we currently have many women in higher education, and then they assume that this will give them access to power. But they overlook the fact that statistically, men have three- or four times better chances of rising to the top and of becoming professors than women do. So, in spite of this bias against women, people still have this feeling that women are taking over. I have met people all around the world saying that since we have $50-60 \%$ female students at the universities, women will soon dominate society, and only men will have gender equality problems in the future." 
Skewes: "It is also what I find in my study in Danish academia where $11 \%$ reported to believe that there currently is reverse discrimination against men in academia" (Skewes, Skewes \& Ryan 2019).

\section{Intersections between Danish Debates on Immigration and Misogyny}

Skewes: "How does Denmark fit into this climate of misogyny, homophobia and xenophobia?"

Dahlerup: "What we need to worry about in Denmark is the new neo-liberal explanations. Look at the motivation behind the former government's financial cut of KVINFO. It was led by politicians from Liberal Alliance (a small neo-liberal party in the Danish parliament) which in their programme explicitly writes that the State ought not to support institutions which 'support certain gender perceptions.' We have many of those institutions, not just KVINFO. We have an Equality Unit in the Ministry. We have the Equality Counsel (in Danish: Ligestillingsnævnet), we have the Institute for Human Rights, with its unit for gender equality. Imagine if we should remove all those institutions! This points to another conflict than the one with the extreme right abroad, because these are neoliberal politicians with well-educated younger men as their main followers, and some women as well. They denounce any structural analysis and claim that it is women's own choices that create the asymmetries that we currently do have."

Skewes: "I often meet this narrative in Denmark that it is women who chose to have less demanding careers and therefore less power. That women are just more drawn to taking care of children and therefore to working part time, so why should we prevent them from making those choices?"

Dahlerup: "That's what I refer to as the neo-liberal assumption that it is women's own choice. The right-wing populists, who are currently in power in Poland and Hungary, would say that women ought to stay at home. They want old-fashioned family structures. But this Danish group is not traditionalists in that way. Instead, they deny that there are any structural barriers and are in general against state intervention in most policy areas"

Skewes: "Haveyou written about this academically?"

Dahlerup: "We are studying these different understandings of what gender equality mean in our new book. For this project, I have conducted a survey among the members of the Danish Parliament, which shows that one third of the Danish Parliamentarians believes that gender equality 'has by and large been achieved' or has 'gone too far'. I label this position 'Equality is a closed case,' inspired by detective novels. I found that most of male MPs from the bourgeois parties belong to this group (Dahlerup 2018c). And we also have a survey among the Danish population of attitudes towards gender equality and gender equality politics, where the results are even more discouraging. What did we feminists do wrong?"

Skewes: "You are in the best position to answer that question. What made us immune to the gender equality discussion in Denmark? Why are we not having this discussion?"

Dahlerup: "The Danes are not traditionalists. They don't want women back in the kitchens, not even the right-wing parties. I believe that part of the explanation of the present deadlock in the Danish gender equality debate is the harsh debate on immigration. Because at its core, feminism and gender equality is about the equal worth of all human beings, and this stands in sharp contrast to the Danish discourse on immigration. Even the Danish People's Party, who has voted against most gender equality legislation, now claim that gender equality is a 'Danish value'. They claim it is only the immigrants who are lagging behind. This discursive construction ensures that, with good conscience, you can vote against all gender equality policies while at the same time justifying that we regulate immigrants' behavior; for instance, by forcing people not to wear the burka. This political approach 
achieves two goals: a) It ensures that we do not have to work on gender equality in Denmark for the 'real' Danes, and b) it redirects our attention to the immigrants that are cast as not being 'real' Danes.

\section{Myths that Prevent Feminist Knowledge Sharing}

Skewes: Besides our immigration debates, do you think there are other elements that stand in the way of the promotion of feminist values in Denmark?"

Dahlerup: "In Denmark, feminism is associated with the radical Redstockings, or rather the myths about the Redstockings Movement. In my work on social movement theory, which describes how all social movements have their ups and downs, I have added that, historically, after a high point in the Women's Movement there will be constructs of myths in the media about what the movement consisted of (Dahlerup 2013). You can see this in the way the newspapers write about the Redstockings Movement. For instance, that 'the Red Stockings hated men' or 'wanted to be like men'; I don't know if you can do both at the same time? But they are two co-exiting myths. These myths hurt the younger generation of women because they then have to distance themselves from the previous wave of feminism. In my generation, we were very scared of being like the Suffragists. The myths were that they were bourgeois spinsters who could not get a man. This meant that we had to invent a new kind of feminist movement to separate ourselves from that myth. I think these negative myths about the Redstockings Movement have been very powerful and destructive for the feminist environment in Denmark (Dahlerup 1986, 1998)."

Skewes: "The way you describe it, the myths work as a divisive, silencing mechanism which prevents information flow between generations."

Dahlerup: "Yes, because it casts the older generation in a negative light which the younger generation needs to distance themselves from. In this way, it prevents collective learning from one generation to the next. It is a great problem in the feminist movement."

Skewes: "It is so interesting that you say that because very early on in my academic career, I was warned about associating with some of the outspoken feminists at my university, women I wanted to network with."

Dahlerup: "I am sorry to hear this. Are you actually talking about being warned against contacting people? I almost can't believe it."

Skewes: "Yes, I was warned against associating with certain people. And now I have been told by several younger researchers that they have been warned against associating with me. I have a strong feminist brand because I founded and still coordinate the Gendering in Research network, so now upcoming researchers are being warned against associating with me. They are being warned that it might have a negative effect on their career to do so. This shows how learning between fellow feminists is being prevented through myths even within generations. It seems to be the smallscale version of what you are describing between generations."

Dahlerup: "Yes it sounds similar. One of the things you have to do to resist this kind of suppression of feminist networking and collective learning is to invite internationally well-known feminist scholars. You need to bring them into the university to debate these issues in the open."

Skewes: "I actively do that via Gendering in Research, but then even my superiors have experienced being confronted and asked to keep me in check and to ensure that I am better aligned with the university's non-feminist agenda."

Dahlerup: "So, what they are really saying is that young scholars should not associate with these well-known scholars exactly because they are successful? Do they use the word 'feminist' when they warn you against affiliating yourself with these researchers?" 
Skewes: "No they have been labelled as 'controversial researchers', yet again questioning the possibility of being both a feminist and a researcher."

\section{Individual Choices or Structural Challenges?}

Skewes: "There clearly is a lot of resistance to both feminist knowledge production in academia and feminist agendas in Denmark in general, but how could we change our approach to gender equity in Denmark in order to achieve greater changes?"

Dahlerup: "I don't think the political parties in Denmark are taking on enough responsibility for the problem. When I compared party programmes from Denmark and Sweden, I found a big difference in the diagnosis of the problem of women's underrepresentation. From around the turn of the millennium, both the Swedish left and the liberal parties began calling themselves 'feminist' and based their diagnosis of the problem on Yvonne Hirdman's concept of the gender system (in Swedish 'könsmaktsordning'). This meant a new focus on changing the structures and barriers in society. However, in Denmark most, parties left the problem undiagnosed (Dahlerup 2007, 2010b).

In Scandinavia, we have moved beyond the claim that the lack of representation is due to women being unintelligent! However, around the world you are still confronted with this argument. I have experienced women arguing that point too. When I was consulting in Cambodia for UNDP, I had a meeting with the female members of parliament. One of them said very early in the discussion 'I'm sure there will be more women in politics when women become more qualified and skilled.' What she was really saying, was that 'we' were the skilled elite, while the rest of Cambodian women were not qualified for politics. By turning the perspective, and asking these parliamentarians how and who recruited them, the old boy's network at work can be revealed. I experienced a similar eye-opener when I was invited to speak at a meeting for parliamentarians on quota adoption in the Ivory Coast. The parliament's highly respected female vice chair effectively stopped a discussion about women not being sufficiently qualified for political work by telling about all her personal difficulties years back, when she had to go from one powerful man to another for years in order to be nominated for a seat (Dahlerup 2018a, 47-48).

However, I think over all that there has been a change in the global discussion, a shift away from blaming women to blaming structures. This important shift arose out the Beijing declaration 'Platform for Action', which was adopted at the 1995 World Conference on Women. Some might think that such international declarations play no role, but I see time and again in my work as an international advisor on the political empowerment of women how local women's organisations make active use of these declarations. They can use these declarations and us as international advisors, to 'squeeze' their top politicians. Therefore, this declarational shift of focus away from the individual women to the institutional structure was essential. I have always worked from what we today label a feminist institutionalist perspective, which focuses on changing the structures of the political system rather than changing the individual women. It is these structural barriers which are still preventing women from moving into politics, not their lack of qualifications. I believe there are enough qualified women out there to fill all the parliaments in the world!"

Skewes: "I feel that this discussion of whether it is the women or the institutions which are at the root of the problem is still considered open for discussion in Denmark. What do you think?"

Dahlerup: "Individual parties always claim that they are looking for women for nomination but that they are simply not there. But at least in the abstract there is an understanding that there is a structural problem. However, in academia we have not successfully finished this shift from an individual to a structural perspective. I think it is this conflict between self-perception and reality which has delayed the change in the universities But I think at least in the abstract, and maybe particularly outside of academia, people recognize 
gender equality is an important principle. It is even a Danish value, right? 'Gender equality' is today part of the so-called Denmark Canon side by side with 'Christian values', 'tolerance', 'welfare state' and 'hygge' (a cozy atmosphere that by many Danes is considered important when socializing with friends).

Skewes: "But as you have shown in your study, gender equality is perceived to be a box we have already ticked off. Denmark is perceived to be a gender equal country, so there is nothing more to strive for on that front."

Dahlerup: "Absolutely, in Denmark we have not developed the thinking and taken the important discussion to a political level; in fact, the discussions have been weakened during the last two decades. So, Denmark has been left behind in a Nordic perspective. There is a connection between a weak discussion and the fact that Denmark, in contrast to the other Nordic countries, has refrained from using those gender equality policy instruments which have proved to make substantial change, such as criminalising the buyers of sex (Sweden, Norway, Finland), a minimum quota for women and men in company boards with sanctions for non-compliance (Norway, Iceland) and earmarking parental leave for the fathers (all other Nordic countries).

\section{The MeToo Movement in Denmark}

Skewes: "Another front where the discussion seems to have been stopped or stalled in Denmark is in relation to the MeToo Movement. Do you agree with my interpretation that Denmark has been relatively immune to the MeToo Movement? (The interview took place prior to Sofie Linde's kick start of Denmark's second wave of \#MeToo). I think that in many other countries, it has spurred both discussions and initiatives aimed at achieving changes whereas in Denmark we have seemed quite immune to those discussions and particularly to the initiatives for change. Even in the case of Zentropa, it just led to temporary sanctions and then everything went back to the former standards of conduct; no institutional learning was achieved."

Dahlerup: "I wouldn't use the word 'immune', but rather say 'less receptive'. An article in the journal Nordicum compares the reception of the MeToo Movement in Denmark and Sweden (Askanius \& Hartley 2019). It shows how the MeToo movement was primarily painted in a positive light in Sweden, while it was primarily painted in a negative light in Denmark. This is a typical finding in Danish-Swedish comparisons, and in line with my own comparative discourse analysis of the two countries during my 18 years as professor at Stockholm University. I think two things happen, when we compare MeToo in Sweden and Denmark. Firstly, it stands out that the actions taken from the political parties and the government were much more efficient and powerful in Sweden. For instance, the Swedish minister of culture, Alice Bah Kuhnke, responded the day after 12 actors on the front page of the newspaper, Dagens Nyheter, accused Dramaten of sexual harassment. She called the leaders of the biggest theaters and asked them which strategies they were going to implement in order to prevent this in the future? It was even debated in the parliament. In contrast, as far as I know, it has never been debated in the Danish parliament. Mette Bork did not even do anything until she was pushed by the press to call a meeting. These actions and inactions are of course part of the legitimation or delegitimisation of this movement and that is one part of the problem. The other part of the problem is what Askanius and Hartley's article clearly shows, namely, that in Denmark there were many men from the cultural elite, and some outspoken women as well, who were using labels such as 'witch hunt' to describe the movement. In spite of the fact that very few Danish men have been named and exposed by the MeToo Movement. In Sweden they also used the term 'witch hunt', but here the primary focus remained on women's exposure to sexual harassment, rather than on men's exposure to accusations of sexual harassment. But I would not use the word 'immune' to describe the Danish reception of the MeToo Movement. I would rather say that the reception has been polarised. This 
can be illustrated by the big hearing about MeToo at Roskilde University in March 2018, which I was part of organising. We invited some of the actors who had reported on sexual harassment problems to speak about their experiences. Several hundred people attended. This shows that many people do want to hear about these experiences. We have the 'Everyday Sexism' website, there have been many other hearings, and the law on sexual harassment has been strengthened somewhat, based on feminist research showing the malpractice. However, others do want to deny that sexual harassment even occurs. But, it is important to underline that the MeToo movement did achieve a lot in Denmark. Everybody has heard of the movement! Most young men have heard about it, and I believe many of them are influenced by it. And all women now know that they do not have to accept this kind of behaviour; that makes a great difference.

But the accusation of a witch hunt on men should be seen as an attempt to stop the discussion, when, what, we were in fact doing, was addressing and fighting sexual harassment and the lack of protection women have from sexual violence. The MeToo Movement has the potential to be revolutionary by changing thousands of years of patriarchal history where men have considered themselves entitled to women's bodies. But the expressed expectation is that not a single man ought to be hurt in the process of this revolution! Is that really a fair and reasonable expectation?"

\section{Notes}

1 From a special issue on Women's Studies (kvindeforskning) of the journal Politica, see Dahlerup 1974, 13.

2 See also the global quota website: www.quotaprojects.org, which I along with my research team at Stockholm University started in cooperation with International IDEA, which gives information to quota advocates all over the world.

3 Anette Borchorst og Drude Dahlerup, Konsensus og konflikt. Det danske ligestillingspolitiske regime. Frydenlund Academics (in Danish).

4 Anette Borchorst and Lise Rolandsen Agustín, Seksuel chikane på arbejdspladsen. Faglige, politiske og retlige spor. Aalborg University Press, 2017.

\section{References}

Childs, S. \& Dahlerup, D. 2018. Increasing women's descriptive representation in national parliaments: the involvement and impact of gender and politics scholars. European Journal of Politics and Gender. 1(0102), 185-204.

Dahlerup, D. 1974. Betragtninger over de nye kvindestudiers baggrund, indhold og perspektiv. Politica. 7(23), 2-53.

Dahlerup, D. 1986. The New Women's Movement. Feminism and Political Power in Europe and the USA. Sage Publications.

Dahlerup, D. 1998. Rødstrømperne: Den Danske Rødstrømpebevægelses Udvikling, Nytænkning og Gennemslag 1970-1985, bd. I-II. København: Gyldendal.

Dahlerup, D. 2010a. Jämställdhet i akademin - en forskningsöversikt. Rapport 2010:1. Stockholm: Delegationen för jämställdhet.

Dahlerup, D. 2010b. Ligestillingsforståelser i svenske og danske partier. Er en borgerlig ligestillingspolitik under udvikling? Politik. 10(2), 68-77. 
Dahlerup, D. 2010c. The Development of Gender and Politics as a New Research Field within the Framework of the ECPR. European Political Science. 9(1), S85-S98.

Dahlerup, D. 2011. När svenska partier blev "feminister" - om skillnader i dansk och svensk jämställdhetsdebatt. I: Freidenvall, L. \& Jansson, M. red. Politik och kritik. En feministisk guide till statsvetenskap. Lund: Studentlitteratur, 193-212.

Dahlerup, D. 2013. Disruption, Continuity and Waves in the Feminist Movement. In: Maddison, S. \& Sawer, M. eds. The Women's Movement in Protest, Institutions and the Internet. Routledge, Chapter 2.

Dahlerup, D. 2018a. Has Democracy Failed Women? Cambridge: Polity Press.

Dahlerup, D. 2018b. Demokrati uden kvinder? København: Forlaget U Press.

Dahlerup, D. 2018c. Gender Equality as a Closed Case: A Survey among the Members of the 2015 Danish Parliament. Scandinavian Political Studies. 41(2), 188-209.

Dahlerup. D. \& Antíc Gaber, M. 2017. The Legitimacy and Effectiveness of Gender Quotas in Politics in CE Europe. Introduction as editors to special section on 'Gender Quotas in Politics in Central East Europe'. Teorija in Praksa. 54(2), 307-316.

Darhour, H. \& Dahlerup, D. 2019. Double-Edged Politics on Women's Rights in the MENA Region. Palgrave Macmillan.

Haavio-Mannila, E., Dahlerup, D., Euards, M., Gudmundsdottir, E., Halsaa, B., Hernes, H. M., Hanninen-Salmelin, E., Sigmundsdottir, B., Sinkkonen, S., Skard, T., \& Badcock, C. (1986). Unfinish Democracy - Women in Nordic Politics. Scandinavia Studies 58(3), 320-322.

Institut for Menneskerettigheder. 2019. Kvinder, demokrati og Folketingsvalg 2019. Analyse. København: Institut for Menneskerettigheder.

Kuhar, R. \& Paternotte, D. (2017). Anti-Gender Campaigns in Europe - Mobilizing Against Equality. Lanham, New York: Rowman \& Littlefield

Pande, R. ed. 2014. A Journey Into Women's Studies - Crossing Interdisciplinary Boundaries. Palgrave Macmillan.

Skewes, L., Skewes, J. C. \& Ryan, K. M. (2019). Attitudes to Sexism and Gender Equality at a Danish University. In Women, Gender \& Research, vol 1.

Wold, A. \& Wennerås C. (1997). Nepotisme and sexism in peer-review. Nature. 387, 341-343

\section{Bibliographies}

Drude Dahlerup's C.V., publications, and assignments can be found on www.drudedahlerup.com

Bibliography of Drude Dahlerup's scholarship 1973-2012 in Freidenvall, L. \& Micheletti, M. eds. (2012). Comparisons, Quotas and Critical Change. Festschrift for Drude Dahlerup. Institute of Political Science, Stockholm University. 